\title{
Diagnostic Accuracy of the NCCN Distress Thermometer for the Assessment of Psychosocial Distress among Filipino Patients with Cancer
}

\author{
Dean Marvin P. Pizarro, MD, Marie Belle I. Francia, MD and Mel Valerie C. Ordinario, MD
}

Cancer Institute, St. Luke's Medical Center Quezon City

\begin{abstract}
Objective. The study aimed to assess the validity of the National Comprehensive Cancer Network Distress Thermometer (NCCN-DT) for determining psychosocial distress, as applied to Filipino patients with cancer.

Methods. We conducted a cross-sectional descriptive study that included adult patients with cancer undergoing treatment at a tertiary private hospital. The NCCN-DT was administered to the patients together with the Patient Health Questionnaire-8 (PHQ-8) as the gold standard diagnostic test for psychosocial distress. Receiver Operating Characteristic (ROC) analysis was done to determine the accuracy of the NCCN-DT as a screening tool.

Results. We included 114 Filipino adults with cancer. The ROC analysis showed an Area Under the ROC Curve (AUC) score of 0.98 for the NCCN-DT against the PHQ-8. The cut-off score of $\geq 7$ showed a sensitivity of $100 \%$ and specificity of $89.3 \%$ for detecting distress. The positive predictors for distress were identified: sadness $(P<0.001)$, fear $(P=0.001)$, depression $(P=0.002)$, worry $(P=0.02)$, childcare $(P=0.03)$, fatigue $(P=0.03)$, treatment decisions $(P=0.04)$, loss of interest in usual activities $(P=0.04)$, and memory/concentration $(P=0.04)$.
\end{abstract}

Conclusion. The NCCN-DT had satisfactory diagnostic accuracy in agreement with PHQ-8 for screening of psychosocial distress among Filipino cancer patients. A cut-off score of $\geq 7$ using the NCCN-DT gave the highest sensitivity and specificity for detecting distress in this population. The findings of this study can be used as validation of the NCCN-DT screening tool for a prospective application.

Keywords: anxiety, depression, Distress thermometer, fear, sadness, Patient Health Questionnaire

\section{INTRODUCTION}

The National Comprehensive Cancer Network (NCCN) defines distress as a multifactorial unpleasant experience of a psychological, social, spiritual, and/or physical nature that may interfere with the ability to cope effectively with cancer, its physical symptoms, and its treatment. The experience has high variability and subjectivity ranging from a common feeling of sadness and helplessness to a much more severe subjective feeling of depression, anxiety, and emotional turmoil that can cause significant physical, mental, and emotional disability.

The NCCN distress management panel developed a screening tool that can identify psychosocial distress through a questionnaire. The tool measures distress on a scale from 0

Corresponding author: Dean Marvin P. Pizarro, MD Cancer Institute

St. Luke's Medical Center

79 E. Rodriguez Sr. Avenue, Quezon City 1112, Philippines

Email: marvinpizarro@gmail.com to 10 with escalating distress severity and a problem checklist for specific distress signals. However, there are currently no published data that confirms the validity of this tool in 
Filipino patients with cancer patients. Its application to Asian patients was done in a Chinese study in which they validated the use of the NCCN-DT with the Hospital Anxiety and Depression Scale (HADS) and Symptom Checklist 90 (SCL-90). It was analyzed using ROC and AUC and MiNi International Neuro-psychiatric Interview (MINI) in those patients with emotional problems as the main cause of distress. The study showed that an NCCN-DT cutoff of 4 yielded a sensitivity of $80 \%$ and specificity of $70 \%$ relative to HADS and a sensitivity of $87 \%$ and specificity of $70 \%$ relative to SCL-90. The most common psychosocial disorders identified were adjustment disorder, depression, and anxiety. ${ }^{1}$

In a similar study, the NCCN-DT was administered to detect depression among women newly diagnosed with breast cancer. The questionnaire was conducted along with Patient Health Questionnaire 9-item Depression Module (PHQ-9) as a gold standard. A score of 7 showed a sensitivity of $81 \%$ and specificity of $85 \%$ for detecting depression. ${ }^{2}$ Its applicability to prostate cancer patients was also validated in Australia using the Impact Event scale and HADS as a comparison. With a cutoff score of $\geq 4$, DT proved to be a valid tool to detect cancer-specific psychosocial distress with a sensitivity of $>85 \%(85.7 \%$ to $92.9 \%)$ with an acceptable specificity (up to $77.5 \%$ ). ${ }^{3}$

Treatment outcomes are affected by psychosocial distress for different reasons, though the direct association is still indeterminate. Distress can have an impact on the depression of immune function causing escape from tumor detection and killing. It also has a significant effect on treatment outcomes by affecting treatment compliance and follow-up. ${ }^{4}$

In this study, we determined the diagnostic accuracy of the NCCN-DT for screening patients with psychosocial distress among Filipino patients with cancer. This study can be used as validation of this screening tool for future clinical application in the Filipino population with cancer.

\section{METHODS}

\section{Study design}

A cross-sectional descriptive study design was used to compare the diagnostic performance of the NCCNDT against the PHQ-8 as the gold standard. The study participants were requested to answer the NCCN-DT and PHQ-8 simultaneously before their scheduled treatment. The participants had the option of answering the English or Tagalog version of the screening tools. The Tagalog version of the NCCN-DT and PHQ-8 used in this study underwent translation and back-translation procedures. The translated NCCN-DT was similar to the latest published version in the NCCN guidelines (Appendices A and B).

\section{Study population}

The participants in this study were cancer patients from St. Luke's Medical Center Cancer Institute who were seen between November 2020 and February 2021. Patients aged
18 years and above, with histopathologic and/or radiologic diagnosis of any type of malignancy, and currently undergoing treatment (surgical/systemic chemotherapy/radiotherapy/ targeted treatment) were included. Patients who could not read and/or write, or could not comprehend or understand the procedure of answering the questionnaire were excluded from this study. The procedure was thoroughly explained by the investigators and an informed consent form was required to be signed by the patients before the conduction of the study. This study was approved by the Institutional Ethics Review Board of the institution.

\section{Instruments}

\section{Distress Thermometer}

The NCCN-DT was used for the initial screening of psychosocial distress. This screening tool consists of a single-item self-report scale inside a thermometer image which had a range of scores from "0" which accounts for "no distress" and a maximum of "10" which accounts for "extreme distress." The patients were instructed to encircle the number corresponding to the perceived level of distress experienced during the past week including the present day. This tool was accompanied by the 39-item problem list on the same page which identifies the specific problems grouped into 5 major categories: practical, family, emotional, spiritual/religious, and physical.

\section{Patient Health Questionnaire-8}

PHQ-8 is a self-administered questionnaire for the screening of depression and its severity. It consists of eight out of the nine original questions set by the PHQ-9 (DSM IV diagnosis of major depressive disorders). The question on suicidal or self-injurious ideations was omitted due to its minor effect on the outcome interpretation and the lack of intervention available during the interview. ${ }^{5}$ The patients were asked about the number of days in the past two weeks and how often they experience the eight symptoms. Each frequency is labeled in an ordinal manner (" 0 " for not at all, "1" for some days of the week, " 2 " for more than half of days in a week, "3" for nearly every day) and the total sum of all scores ranges from 0 to 24 points. A positive result was defined as a total score of $\geq 10$ which has a sensitivity of $88 \%$ and specificity of $88 \%$ for major depression. ${ }^{5}$ This tool was used as the gold standard comparator.

\section{Statistical analysis}

The demographic profile of the patients was described in means and percentages. The study used the PHQ-8 as the gold standard screening tool for detecting distress. ROC analyses were used to determine the accuracy of the NCCNDT as a screening tool. The PHQ-8 cutoff score of $\geq 10$ was used to identify patients who are screened positive and the sensitivities and specificities of each score in the NCCNDT were calculated using STATA Statistics Data Analysis. 
The correlation of significance between each problem list variable and NCCN-DT positive score were analyzed in a two-dimensional cross-comparison table and tested using the Chi-square test. The reported $\mathrm{P}$ values were two-sided and $\mathrm{P}$ values $<0.05$ were considered statistically significant. The median scores of NCCN-DT and PHQ-8 were removed in the final report since they did not have an impact and/or relevance in the diagnostic accuracy assessment.

\section{RESULTS}

\section{Patient characteristics}

The total population included in the final analysis was 114 patients. The demographics and baseline characteristics are listed in Table 1 . The majority of the patients included

Table 1. Patient demographics and baseline characteristics

\begin{tabular}{|c|c|c|c|}
\hline & & $\mathrm{n}$ & $\%$ \\
\hline \multirow[t]{2}{*}{ Sex } & Male & 24 & 21.1 \\
\hline & Female & 90 & 78.9 \\
\hline \multirow[t]{4}{*}{ Age } & Below 40 & 18 & 15.8 \\
\hline & $40-49$ & 18 & 15.8 \\
\hline & $50-79$ & 78 & 68.4 \\
\hline & $80 \&$ above & 0 & 0.0 \\
\hline \multirow[t]{4}{*}{ Marital Status } & Single & 20 & 17.5 \\
\hline & Married/Partner & 74 & 64.9 \\
\hline & Separated & 17 & 14.9 \\
\hline & Widowed & 3 & 2.6 \\
\hline \multirow[t]{9}{*}{ Cancer Type } & Breast & 71 & 62.3 \\
\hline & Lower GI & 16 & 14.0 \\
\hline & Gynecologic & 10 & 8.8 \\
\hline & Head and Neck & 5 & 4.4 \\
\hline & Hematolymphoid & 4 & 3.5 \\
\hline & Upper GI & 3 & 2.6 \\
\hline & Lung & 3 & 2.6 \\
\hline & Pancreatic & 1 & 0.9 \\
\hline & Genitourinary & 1 & 0.9 \\
\hline \multirow[t]{4}{*}{ Stage } & 1 & 3 & 2.6 \\
\hline & II & 28 & 24.6 \\
\hline & III & 27 & 23.7 \\
\hline & IV & 56 & 49.1 \\
\hline \multirow[t]{4}{*}{ Educational Level } & Primary & 3 & 2.6 \\
\hline & Secondary & 23 & 20.2 \\
\hline & College & 82 & 71.9 \\
\hline & $\mathrm{PhD}$ & 6 & 5.3 \\
\hline \multirow[t]{6}{*}{ Salary Grade (Php) } & $<150,000$ & 41 & 36.0 \\
\hline & $150,000-349,999$ & 22 & 19.3 \\
\hline & $350,000-599,999$ & 21 & 18.4 \\
\hline & $600,000-1,700,000$ & 17 & 14.9 \\
\hline & $>1,700,000$ & 6 & 5.3 \\
\hline & Undisclosed & 7 & 6.1 \\
\hline \multirow[t]{2}{*}{ Place of Treatment } & Inpatient & 5 & 4.4 \\
\hline & Outpatient & 109 & 95.6 \\
\hline
\end{tabular}

were women (78.9\%) and were treated in the outpatient setting (95.6\%). Most of the patients belonged to the age group of 50-79 years (68.4\%). The majority of the patients were married or have a long-term partner (64.9\%) at the time of the interview. The most common cancer type in the population was breast cancer (62.3\%) and almost half of the population had metastatic disease. Almost seventy-two percent $(71.9 \%)$ had a college degree. Notably, 36.0\% had an annual income of below Php 150,000.

\section{Outcomes}

A ROC analysis was performed to confirm the accuracy of the NCCN-DT (Figure 1 and Table 2.2). The AUC of the NCCN-DT was 0.98 (against PHQ-8). The greater the height of the curve above the chance line (AUC $=0.5$ ), the more accurate the result is. The cutoff score of $\geq 7 \mathrm{had}$ the highest diagnostic accuracy in agreement with the PHQ-8 questionnaire as the gold standard. It showed a sensitivity of $100 \%$ and a specificity of $89.3 \%$ (Table 2.1 ).

Table 2.1. Sensitivity and Specificity of NCCN-DT scores

\begin{tabular}{ccc} 
NCCN-DT cutoff scores & Sensitivity (\%) & Specificity (\%) \\
\hline 0 & 0.00 & 100.00 \\
1 & 18.18 & 100.00 \\
2 & 24.68 & 100.00 \\
3 & 37.66 & 100.00 \\
4 & 51.95 & 100.00 \\
5 & 66.23 & 100.00 \\
6 & 93.51 & 92.86 \\
7 & 100.00 & 89.29 \\
8 & 100.00 & 39.29 \\
9 & 100.00 & 3.57 \\
10 & 100.00 & 0.00 \\
\hline
\end{tabular}

NCCN-DT, National Comprehensive Cancer Network Distress Thermometer

Table 2.2. Area under ROC of NCCN-DT

\begin{tabular}{ccccc} 
Obs & ROC Area & Std. Err. & Asymptotic Normal (95\% CI) \\
\hline 105 & 0.9845 & 0.0104 & 0.96411 & 1.0000 \\
\hline
\end{tabular}

NCCN-DT, National Comprehensive Cancer Network Distress Thermometer

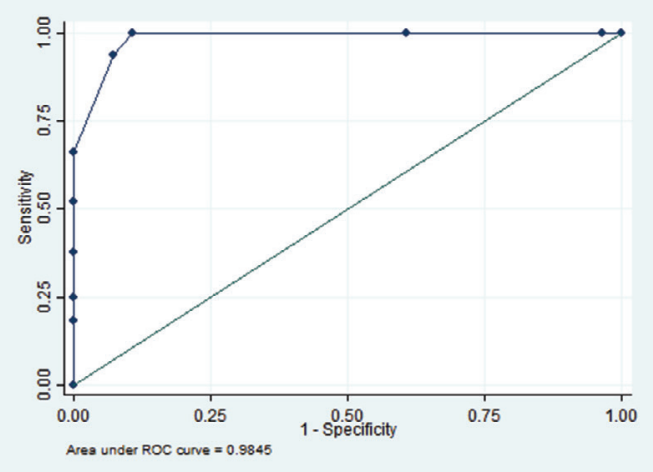

Figure 1. ROC curve of NCCN-DT against PHQ-8. 
The most common problems identified in the NCCNDT Problem List were as follows: worry (61.1\%), fatigue (51.8\%), insurance/financial (37.7\%), and sadness (36.6\%). Of all the problems identified in the list, these variables had a significant positive correlation with the NCCN-DT result: sadness $(\mathrm{P}<0.001)$, fear $(\mathrm{P}=0.001)$, depression $(\mathrm{P}=0.002)$, worry $(\mathrm{P}=0.019)$, childcare $(\mathrm{P}=0.031)$, fatigue $(\mathrm{P}=0.032)$ treatment decisions $(\mathrm{P}=0.037)$, loss of interest in usual activities $(\mathrm{P}=0.037)$, and memory/concentration $(\mathrm{P}=0.044)$ (Table 3).

Table 3. NCCN-DT Problem List

\begin{tabular}{|c|c|c|}
\hline & Frequency $\mathrm{n}(\%)$ & p-value \\
\hline Child care & $9(7.89)$ & 0.031 \\
\hline Food & $2(1.75)$ & 0.446 \\
\hline Housing & $13(11.40)$ & 0.736 \\
\hline Insurance/Financial & $43(37.72)$ & 0.072 \\
\hline Transportation & $16(14.04)$ & 0.548 \\
\hline Work/School & $14(2.39)$ & 0.346 \\
\hline Treatment decisions & $27(23.68)$ & 0.037 \\
\hline Dealing with children & $10(8.77)$ & 1.000 \\
\hline Dealing with partner & $6(5.26)$ & 1.000 \\
\hline Ability to have children & $1(0.88)$ & 0.254 \\
\hline Family health issues & $17(14.91)$ & 1.000 \\
\hline Depression & $12(10.71)$ & 0.002 \\
\hline Fears & 38 (33.63) & 0.001 \\
\hline Nervousness & $32(28.07)$ & 0.065 \\
\hline Sadness & $41(36.61)$ & $<0.001$ \\
\hline Worry & 69 (61.06) & 0.019 \\
\hline Loss of interest in usual activities & $27(23.68)$ & 0.037 \\
\hline Spiritual/Religious concerns & $4(3.57)$ & 1.000 \\
\hline Appearance & $26(22.81)$ & 0.753 \\
\hline Bathing/Dressing & $13(11.40)$ & 0.510 \\
\hline Changes in urination & $11(9.65)$ & 1.000 \\
\hline Constipation & $20(17.54)$ & 0.606 \\
\hline Diarrhea & $14(12.28)$ & 0.113 \\
\hline Eating & $30(26.32)$ & 0.426 \\
\hline Fatigue & $59(51.75)$ & 0.032 \\
\hline Feeling swollen & $9(7.89)$ & 1.000 \\
\hline Fevers & $2(1.75)$ & 1.000 \\
\hline Getting around & 18 (15.79) & 0.236 \\
\hline Indigestion & 9 (7.89) & 0.229 \\
\hline Memory/Concentration & $14(12.28)$ & 0.044 \\
\hline Mouth sores & $12(10.53)$ & 0.291 \\
\hline Nausea & $14(12.28)$ & 0.113 \\
\hline Dry nose/congested & $7(6.14)$ & 0.188 \\
\hline Pain & $34(29.82)$ & 0.760 \\
\hline Sexual & $3(2.63)$ & 1.000 \\
\hline Skin dry/itchy & $16(14.04)$ & 0.352 \\
\hline Sleep & $34(29.82)$ & 0.525 \\
\hline Substance abuse & $1(0.88)$ & 1.000 \\
\hline Tingling in hands and feet & $24(21.05)$ & 0.560 \\
\hline
\end{tabular}

NCCN-DT, National Comprehensive Cancer Network Distress Thermometer

\section{DISCUSSION}

The diagnosis and management of cancer involve not only the physical health but also the mental well-being of the patients. The patients' perception of their illness is very important for the subsequent treatment plans, management of potential complications, and acceptance of prognosis. The internal experience of distress may not always be overtly visible to the healthcare provider, and this may lead to the under-recognition of this ordeal. In this study, we determined the diagnostic accuracy of the NCCN-DT and problem list in agreement with the commonly used PHQ-8 questionnaire in screening for psychosocial distress among Filipino cancer patients.

According to a local study, the prevalence of distress has a very wide range on medically ill patients using the HADS. However, the population studied was composed of heterogeneous medical and/or surgical illnesses and the representation of cancer patients was only $6.4 \% .{ }^{6}$ The selection of the PHQ-8 tool as the gold standard comparator was based on the evidence from a population- and diseasespecific study by Que et al. wherein they used the PHQ-8 to determine the prevalence of depression among Filipino cancer patients. They included malignant cases of different primary sites as compared to other studies cited which were site-specific. ${ }^{7}$ Furthermore, a Swedish study compared the reliability of PHQ and HADS in evaluating depression and anxiety in medical outpatients and showed that both were similar in identifying the prevalence of the study outcomes. ${ }^{8}$

The NCCN-DT provides an objective parameter for the severity of distress upfront and has the advantage of pointing out key problems that may have led to such perception. It is more focused on the specific signs and symptoms experienced by patients with cancer, especially those who are undergoing treatment. It dissects the individual aspects of the general problems that are encountered as compared to the conventional screening tools wherein the emotional/ psychological and physical aspects are only tackled broadly. This tool can point out factors that are needed to be addressed by the caregiver to palliate the perception of distress.

In this study, the prevalence rate of distress was 28.1\% among the total population screened. The most common problems identified were worry (61.1\%), fatigue (51.8\%), insurance/financial (37.7\%), and sadness (36.6\%). Interestingly, the vast majority had a college degree $(71.9 \%)$, while a third of the total population (36.0\%) only had an annual income of less than Php 150,000. This was consequently shown to have affected the patients as financial distress was one of the most identified variables in the problem list, albeit its non-statistical significance $(\mathrm{P}=0.07)$. The prevalence of fatigue can be attributed to the patient's current systemic treatment and/or the physical manifestation of the disease itself; $49.1 \%$ had metastatic disease. The positive predictors of distress identified were sadness $(\mathrm{P}<0.001)$, fear $(\mathrm{P}=0.001)$, depression $(\mathrm{P}=0.002)$, worry $(\mathrm{P}=0.02)$, childcare 
$(\mathrm{P}=0.03)$, fatigue $(\mathrm{P}=0.03)$ treatment decisions $(\mathrm{P}=0.04)$, loss of interest in usual activities $(\mathrm{P}=0.04)$, and memory/ concentration $(\mathrm{P}=0.04)$.

An AUC greater than 0.5 (0.98) means that the NCCNDT is a good screening tool for psychosocial distress in this population. A score of $\geq 4$ corresponds to a positive finding of psychosocial distress according to the NCCN distress management panel based on a meta-analysis of 42 studies with a sensitivity of $81 \%$ and specificity of $72 \% .{ }^{9}$ In this study, the researchers determined the optimal cutoff score for the Filipino cancer patients and the results showed that a score of $\geq 7$ had the highest sensitivity (100\%) and specificity (89.3\%) when compared to the PHQ-8 questionnaire. Hegel et al. showed similar findings in patients with breast cancer. ${ }^{2}$ A Dutch trial also showed that increasing the cut-off score to $\geq 7$ resulted in higher specificity and an acceptable sensitivity as compared to the recommended score of $\geq 4$ which only had a pooled sensitivity of $81 \%$ and specificity of $72 \% .{ }^{10}$

The limitations of this study are as follows. First, due to the limited number of patients enrolled, a multivariate analysis of the correlation between each distress tool score and specific problem list variables cannot be accomplished. Second, the recruitment was mainly focused on the outpatient setting. It is also important to note that this study was conducted during the time of the COVID-19 pandemic. The difference in treatment settings and nationwide healthcare scenarios could have an effect on the overall perception of distress during treatment.

\section{CONCLUSION}

The NCCN-DT is a valid screening tool for psychosocial distress in Filipino cancer patients. A score cutoff of $\geq 7$ using the NCCN-DT was shown to have the highest sensitivity and specificity for detecting distress in this population.

\section{Statement of Authorship}

All authors participated in the data collection and analysis and approved the final version submitted.

\section{Author Disclosure}

All authors declared no conflicts of interest.

\section{Funding Source}

No funding support.

\section{REFERENCES}

1. Tang LL, Zhang YN, Pang Y, Zhang HW, Song LL. Validation and reliability of distress thermometer in Chinese cancer patients. Chin J Cancer Res. 2011; 23(1):54-8.

2. Hegel MT, Collins ED, Kearing S, Gillock KL, Moore CP, Ahles TA. Sensitivity and specificity of the Distress Thermometer for depression in newly diagnosed breast cancer patients. Psycho-oncology. 2008; 17(6):556-60.

3. Chambers SK, Zajdlewicz L, Youlden DR, Holland JC, Dunn J. The validity of the distress thermometer in prostate cancer populations. Psycho-oncology. 2014; 23(2):195-203.

4. Fang CY, Schnoll RA. Impact of psychological distress on outcomes in cancer patients. Expert Rev Pharmacoecon Outcomes Res. 2002; 2(5):495-506.

5. Kroenke K, Strine TW, Spitzer RL, Williams JB, Berry JT, Mokdad $\mathrm{AH}$. The PHQ-8 as a measure of current depression in the general population. J Affect Disord. 2009; 114(1-3):163-73.

6. De Guzman MLR. A validation of the Hospital Anxiety and Depression Scale (HADS-P) in the medically-Ill. Acta Med Philipp. 2013; 47(3):53-62.

7. Que JC, Sy Ortin TT, Anderson KO, Gonzalez-Suarez CB, Feeley TW, Reyes-Gibby CC. Depressive symptoms among cancer patients in a Philippine tertiary hospital: prevalence, factors, and influence on health-related quality of life. J Palliat Med. 2013; 16(10):1280-4.

8. Hansson M, Chotai J, Nordstöm A, Bodlund O. Comparison of two self-rating scales to detect depression: HADS and PHQ-9. Br J Gen Pract. 2009; 59(566):e283-8.

9. Ma X, Zhang J, Zhong W, Shu C, Wang F, Wen J, et al. The diagnostic role of a short screening tool--the distress thermometer: a metaanalysis. Support Care Cancer. 2014; 22(7):1741-55.

10. Ploos van Amstel FK, Tol J, Sessink KH, van der Graaf WTA, Prins JB, et al. A specific distress cutoff score shortly after breast cancer diagnosis. Cancer Nurs. 2017; 40(3):E35-E40. 


\section{APPENDICES}

\section{Appendix A}

NCCN Distress Thermometer (Version 2.2021)

Instructions: Please circle the number (0-10) that best describes how much distress you have been experiencing in the past week including today.

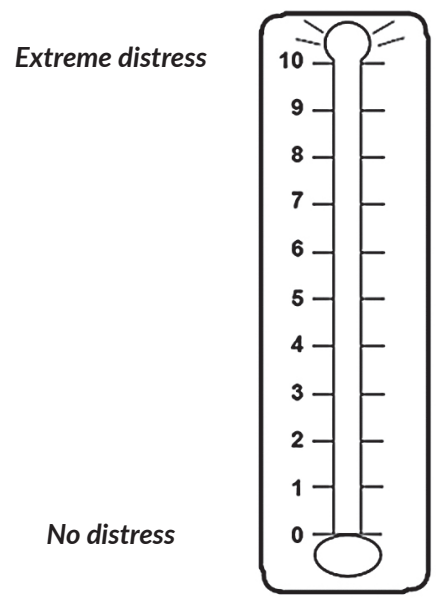

Patient Health Questionnaire (PHQ-8)

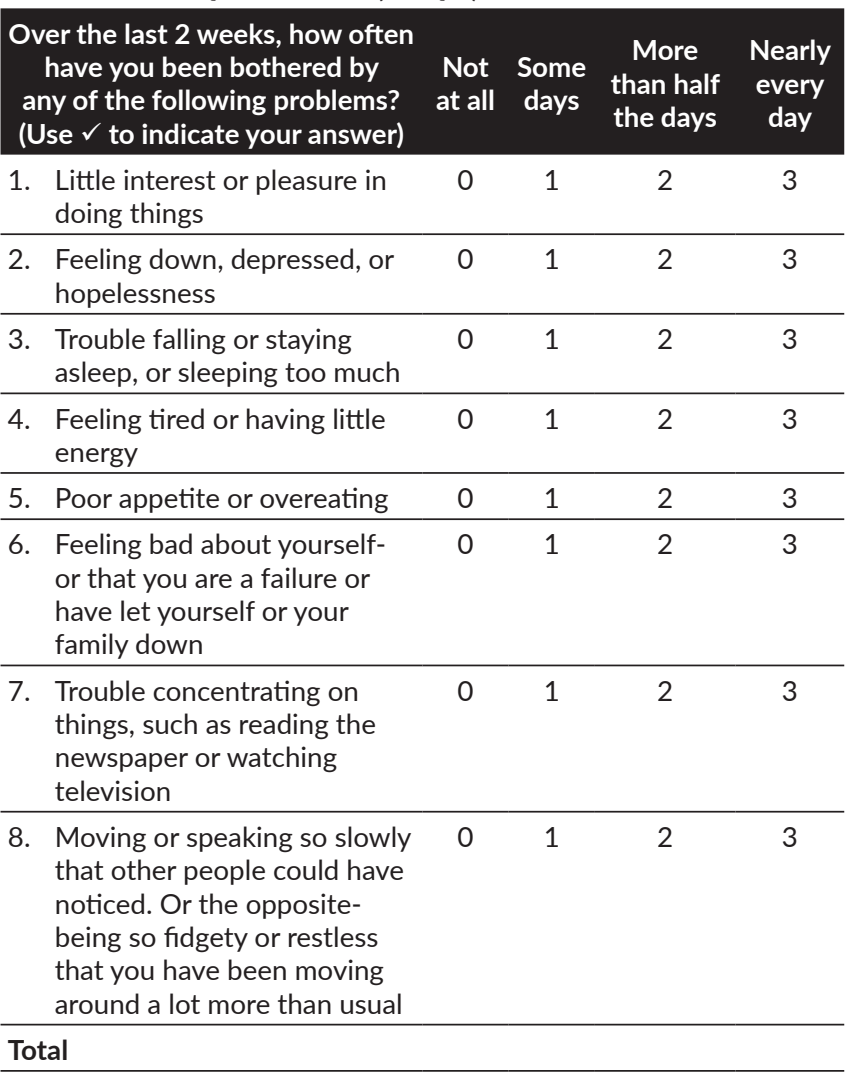

Problem List

Please indicate if any of the following has been a problem for you in the past week including today. Be sure to check YES or NO for each.

\begin{tabular}{|c|c|c|}
\hline YES & NO & Practical Problems \\
\hline \multicolumn{3}{|r|}{ Child care } \\
\hline \multicolumn{3}{|c|}{ Food } \\
\hline \multicolumn{3}{|r|}{ Housing } \\
\hline \multicolumn{3}{|r|}{ Insurance/Financial } \\
\hline \multicolumn{3}{|r|}{ Transportation } \\
\hline \multicolumn{3}{|r|}{ Work/School } \\
\hline \multicolumn{3}{|r|}{ Treatment decisions } \\
\hline \multirow[t]{5}{*}{ YES } & NO & Family Problems \\
\hline & & Dealing with children \\
\hline & & Dealing with partner \\
\hline & & Ability to have children \\
\hline & & Family health issues \\
\hline \multirow[t]{8}{*}{ YES } & NO & Emotional Problems \\
\hline & & Depression \\
\hline & & Fears \\
\hline & & Nervousness \\
\hline & & Sadness \\
\hline & & Worry \\
\hline & & Loss of interest in usual activities \\
\hline & & Spiritual/religious concerns \\
\hline \multirow[t]{22}{*}{ YES } & NO & Physical Problems \\
\hline & & Appearance \\
\hline & & Bathing/dressing \\
\hline & & Changes in urination \\
\hline & & Constipation \\
\hline & & Diarrhea \\
\hline & & Eating \\
\hline & & Fatigue \\
\hline & & Feeling swollen \\
\hline & & Fevers \\
\hline & & Getting around \\
\hline & & Indigestion \\
\hline & & Memory/concentration \\
\hline & & Mouth sores \\
\hline & & Nausea \\
\hline & & Nose dry/congested \\
\hline & & Pain \\
\hline & & Sexual \\
\hline & & Skin dry/itchy \\
\hline & & Sleep \\
\hline & & Substance abuse \\
\hline & & Tingling in hands and feet \\
\hline bro & & \\
\hline
\end{tabular}




\section{Appendix B}

Distress Thermometer ng NCCN (Bersyon 2.2021)

Ang pagkabalisa ay isang hindi kaaya-ayang karanasan ng kaisipan, pisikal, panlipunan, o espiritwal. Maaari nitong maapektuhan ang iyong paraan ng pag-iisip, nararamdaman, o aksyon. Mas pinapahirap ng pagkabalisa ang makayanan ang pagkakaroon ng kanser, mga sintomas nito, o mga paggagamot nito.

Mga tagubilin: Mangyaring bilugan ang numero (0-10) na pinakamahusay na naglalarawan kung gaano kalala ang nararanasan mong pagkabalisa sa nakalipas na linggo kasama na ang ngayong araw.

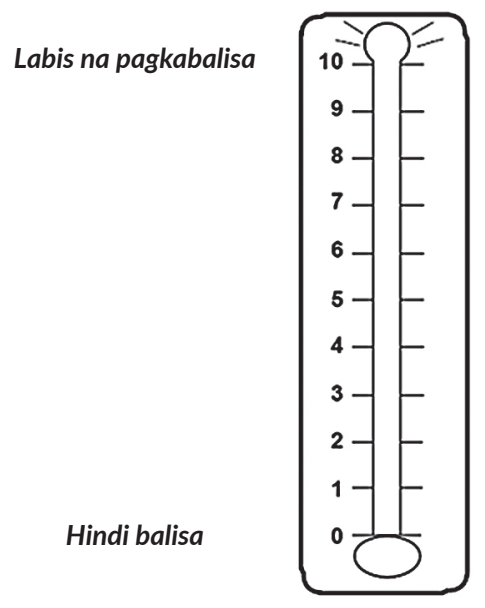

Patient Health Questionnaire (PHQ-8)

\begin{tabular}{lcccc}
$\begin{array}{l}\text { Sa huling dalawang (2) linggo, } \\
\text { gaano kadalas kang naabala ng } \\
\text { alinman sa mga sumusunod na } \\
\text { problema: (Gamitin ang } \checkmark \text { upang } \\
\text { ipahiwatig ang iyong sagot) }\end{array}$ & $\begin{array}{c}\text { Hindi } \\
\text { talaga }\end{array}$ & $\begin{array}{c}\text { May } \\
\text { ilang } \\
\text { araw }\end{array}$ & $\begin{array}{c}\text { Mahigit } \\
\text { sa } \\
\text { kalahati } \\
\text { ng mga } \\
\text { araw }\end{array}$ & $\begin{array}{c}\text { Halos } \\
\text { araw- } \\
\text { araw }\end{array}$ \\
$\begin{array}{l}\text { 1. } \begin{array}{l}\text { Konting interes o kasiyahan } \\
\text { sa paggawa ng mga bagay }\end{array} \\
\text { 2. }\end{array}$ & 0 & 1 & 2 & 3 \\
$\begin{array}{l}\text { Pakiramdam ng nalulungkot, } \\
\text { nalulumbay, o walang pag-asa }\end{array}$ & 0 & 1 & 2 & 3 \\
\hline 3. $\begin{array}{l}\text { Nagkakaproblema sa } \\
\text { pagtulog o sobrang pagtulog }\end{array}$ & 0 & 1 & 2 & 3 \\
\hline 4. $\begin{array}{l}\text { Pakiramdam ng pagod o pag- } \\
\text { kakaroon ng kaunting lakas }\end{array}$ & 0 & 1 & 2 & 3 \\
\hline 5. $\begin{array}{l}\text { Walang gana o labis na } \\
\text { pagkain }\end{array}$ & 0 & 1 & 2 & 3 \\
\hline 6. $\begin{array}{l}\text { Masamang pakiramdam } \\
\text { tungkol sa iyong sarili- o } \\
\text { pagkabigo o pakiramdam na } \\
\text { pinabayaan mo ang iyong } \\
\text { sarili o ang iyong pamilya }\end{array}$ & 0 & 1 & 2 & 3 \\
\hline 7. $\begin{array}{l}\text { Nagkakaproblema sa pagtuon } \\
\text { sa mga bagay, tulad ng } \\
\text { pagbabasa ng pahayagan o } \\
\text { panonood ng telebisyon }\end{array}$ & 0 & 1 & 2 & 3 \\
\hline 8. $\begin{array}{l}\text { Mabagal sa pagkilos o pagsa- } \\
\text { salita na napansin ng ibang } \\
\text { tao. O ang kabaligtaran - hindi } \\
\text { mapakali o hindi mapalagay } \\
\text { na nagdudulot ng pagkilos } \\
\text { nang mas higit sa dati }\end{array}$ & 0 & 1 & 2 & 3 \\
\hline Total & & & & \\
\hline
\end{tabular}

Listahan ng Problema

Mangyaring ipahiwatig kung ang alinman sa sumusunod ay naging problema para sa iyo sa nakalipas na linggo kasama na ang ngayong araw. Siguraduhing tsekan ang OO o HINDI sa bawat isa.

\section{OO HINDI Problemang Praktikal}

Pangangalaga sa bata

Pagkain

Pabahay

Insurance/Pinansyal

Transportasyon

Trabaho/Paaralan

Mga desisyon sa paggagamot

OO HINDI Mga Problema sa Pamilya

Pakikitungo sa mga bata

Pakikitungo sa ka-partner

Kakayanan na magkaroon ng anak

Mga problema sa kalusugan ng pamilya

OO HINDI Mga Problemang Emosyonal

\begin{tabular}{ll} 
& Pagkabalisa \\
\hline & Mga takot \\
\hline Kinakabahan \\
\hline Kalungkutan \\
\hline Pagkabahala \\
\hline Kawalan ng interes sa mga karaniwang aktibidad \\
\hline OO & Mga Alalahaning Espiritwal/Relihiyon \\
\hline & HINDI Problemang Pisikal
\end{tabular}

\begin{tabular}{ll} 
& Hitsura \\
\hline Pagligo/Pagbibihis \\
\hline Paghinga \\
\hline Pagbabago sa pag-ihi \\
\hline Pagtitibi \\
\hline Pagtatae \\
\hline Pagkain \\
\hline Pakiramdam ng namamaga \\
\hline Mga lagnat \\
\hline Paglilibot \\
\hline Hindi pagkatunaw ng pagkain \\
\hline Memorya/konsentrasyon \\
\hline Mga sugat sa bibig \\
\hline Pagduduwal \\
\hline Pagkatuyo ng ilong/barado \\
\hline Kirot \\
\hline Sekswal \\
\hline Panunuyo/pangangati ng balat \\
\hline Pagtulog \\
\hline Paggamit ng bawal na gamot \\
\hline Pamamanhid ng mga kamay/paa \\
\hline Iba pang mga problema: \\
\hline
\end{tabular}

Iba pang mga problema: 